\title{
Expression of oestrogen receptor beta (ERß) occurs in multiple cell types, including some germ cells, in the rat testis
}

\author{
P T K Saunders, J S Fisher, R M Sharpe and M R Millar
}

MRC Reproductive Biology Unit, 37 Chalmers Street, Edinburgh EH3 9EW, UK.

(Requests for offprints should be addressed to P TK Saunders)

\begin{abstract}
The identification of a second oestrogen receptor (beta) has prompted a re-evaluation of the potential sites of action of oestrogens. The aim of the present study was to characterise immunoexpression of ERß expression in the testis to complement earlier data which had demonstrated that expression of $\mathrm{ER} \alpha$ is confined to testicular interstitial Leydig cells. In all testes studied, including those from both fetal (day 20.5 p.c.) and adult rats, ERß was found to be expressed in multiple cell types. Sertoli cell nuclei were immunopositive at all ages. In
\end{abstract}

adult testes expression in Sertoli cells was not stage dependent and was unaffected by ablation of Leydig cells. In fetal testes ERß was also expressed in peritubular cells, fetal Leydig cells and gonocytes. In the pubertal and adult testis ERB was detected in the nuclei of spermatogonia and most pachytene spermatocytes. Weak immunopositive staining was present in the cytoplasm of spermatocytes undergoing the second meiotic division. In conclusion the widespread expression of ER 3 in the testis is consistent with a role for oestrogens in modulating spermatogenesis, and hence fertility, in the male.

\section{Introduction}

The observations that prenatal exposure to the potent oestrogen, diethylstilbestrol (DES) can have adverse effects on sperm count and formation of the male genital tract (Stillman 1982) have prompted the controversial suggestion that inappropriate exposure to oestrogens during life may contribute to adverse trends in male reproductive health (Sharpe \& Skakkebaek 1993; Toppari et al. 1996). A role for oestrogens in normal male fertility has been inferred from the finding that adult male mice in which normal expression of oestrogen receptor $(E R \alpha)$ has been disrupted (ERKO, Eddy et al. 1996) are infertile and evidence that genetic defects in ER $\alpha$ in human males results in decreased sperm counts (Smith et al. 1994). However the finding of a second oestrogen-specific receptor (referred to as ERß) in 1996 (Kuiper et al. 1996) necessitates a re-evaluation of the sites of action(s) of oestrogens. In the male a comparison of the sites of expression of mRNAs encoding the two receptors by reverse transcription PCR (Kuiper et al. 1997; Li et al. 1997) has revealed that multiple tissues in the male tract express both receptor types though this approach gives no indication of cell specific distribution in complex tissues such as the testis.

In a preliminary survey of sites of expression of ERB of using a specific polyclonal antiserum we had noted expression of this receptor in adult rat Sertoli cells (Saunders et al. 1997) which we have shown previously not to express ER $\alpha$ (Fisher et al. 1997). The present study has focused specifically upon the pattern of expression of ERB in the testis of rats using tissue from fetal, neonatal, immature and adult animals (both control and after Leydig cell ablation). To our surprise we have found that immunoreactivity specific for a peptide in rat ERß is present in the nuclei of multiple testicular cell types including Sertoli cells, peritubular cells, Leydig cells and certain germ cell types in all ages of rat examined. We conclude that oestrogens could have a significant role to play in normal testicular function throughout life and that steroids binding to $E R B$ could have direct effects on germ cell function and maturation.

\section{Materials and Methods}

\section{Tissue collection}

Adult female rats were placed in individual cages with male rats and checked for the presence of copulating plugs each morning. The day when the plug was found was taken as day 0.5 post coitum (p.c.). Pregnant females were killed on day 20.5 p.c. by inhalation of carbon dioxide and subsequent cervical dislocation, fetuses were examined under a dissecting microscope and the testes recovered. Testes obtained from fetal rats and those who were $3,5,7,10,14,18$ and 21 days of age were immersion fixed in Bouins for $5-6 \mathrm{~h}$ before being transferred into $70 \% \mathrm{v} / \mathrm{v}$ ethanol for storage. Testes from adult rats were obtained following perfusion fixation with Bouins fixative (Millar et al. 1993). After fixation, testes were pro cessed into paraffin wax, $5 \mu \mathrm{m}$ thick sections were cut and mounted on coated slides, dewaxed and rehydrated prior to immunohistochemistry as described previously (Millar et al. 1993). To induce complete testosterone withdrawal, rats were 
administered a single intraperitoneal injection of $75 \mathrm{mg} / \mathrm{kg}$ ethane dimethane sulphonate (EDS) in 3:1 (v/v) water:dimethyl sulphoxide and perfusion-fixed 6 days later. This treatment results in destruction and removal of all of the Leydig cells within 30-36h (Sharpe et al. 1990).

\section{Immunohistochemistry}

ERß was immunolocalised to testicular cells using rabbit polyclonal anti-peptide IgGs raised against a specific peptide located in the D region of rat ERß as described in detail in Saunders et al. (1997). IgGs were diluted $1 / 100$ to $1 / 250$ and incubated for $48 \mathrm{~h}$ at $4^{\circ} \mathrm{C}$ on sections that had been subjected to microwave antigen retrieval (Shi et al. 1993). To detect bound antibody, sections were incubated with biotinylated swine antirabbit immunoglobulins (Dako, Glostrup, Denmark) diluted 1:500 in NSS-TBS (normal swine serum (NSS) 0.5 parts: normal rat serum 0.5 parts: 5 parts Tris buffered saline (TBS) containing 5\% (w/v) BSA, $30 \mathrm{~min}$ ), washed in TBS (twice, $5 \mathrm{~min}$ each) and incubated with horseradish peroxidase-avidin biotin complex (Dako) for $30 \mathrm{~min}$. After additional washes in TBS (twice, 5 min each) bound antibodies were visualized using $0.05 \%$ (w/v) 3,3'-diaminobenzidine tetra-hydrochloride (DAB, Sigma Chemical Co. Poole, Dorset) in $0.05 \mathrm{M}$ Tris-HCl, pH 7.4 and $0.01 \%$ hydrogen peroxide. Sections were lightly counterstained with haematoxylin. Oestrogen receptor alpha (ER $\alpha)$ was immunolocalised using a mouse monoclonal antibody directed against the $\mathrm{A} / \mathrm{B}$ domain of the receptor according to the methods described in Fisher et al. (1997). The antibody was obtained from Novocastra (Newcastle, UK).

\section{Results}

\section{Fetal and neonatal testes}

On day 20.5 of fetal life ERß was immunolocalised to multiple cell nuclei within the testis including clumps of fetal Leydig cells (Fig 1a, L) and nuclei of cells closely applied to the outside of the seminiferous cords (Fig 1a, b white arrows) which may be Leydig cell precursors or peritubular myoid cells. Within the seminiferous cords the intensity of immunopositive signal in Sertoli cell nuclei (Fig 1b black arrowheads) varied from faint $(+)$ to strong $(+++)$. The large round nuclei of fetal gonocytes (Fig 1b asterisks) were stained intensely $(+++/$ ++++ ). In contrast, ER $\alpha$ immunostaining was confined to cells within the interstitium (Fig 1c) consistent with previous reports that these receptors are expressed in fetal and adult Leydig cells (Fisher et al. 1997). In the neonatal testis, Sertoli cell nuclei remained immunopositive (e.g. day 3, Fig 1d, black arrowheads) and on this day, and days 5 and 7 (not shown), nuclei of interstitial cells and large round germ cells, presumed to be gonocytes, were also immunopositive (asterisk, Fig 1d).

\section{Immature and adult testis}

Sertoli cell nuclei were immunopositive in all samples examined from immature (day 10 Fig le), day 14 (not shown) and day 21 (Fig 1f) testes in which they formed a distinct, almost continuous layer of cells. On day 10 basal spermatogonia (Fig 1e, white arrowheads) were also stained. At day 21, the pattern of immunopositive cell nuclei was variable depending upon the complement of germ cells present in the tubule cross sections with prominent staining of basal spermatogonia and luminal pachytene spermatocyes (asterisk, Fig 1f) being observed. In the adult rat, ERß was localised to SC at all stages of the spermatogenic cycle (e.g Fig 1g, h, black arrowheads) and expression was not reduced in testes from animals in which Leydig cells had been ablated 6 days previously (Fig 1i, j, k, black arrowheads).

Immunopositive staining was also detected in intermediate and B-type spermatogonia (++, e.g. Fig $1 \mathrm{j}$, white arrowheads) but was absent from leptotene, zygotene and early pachytene spermatocytes in stages XIV (Fig 1k, square bracket) and I. Immunopositive staining for ERB was present in the nuclei of pachytene spermatocytes between stages III and XII and was most intense at stages V to XI (e.g. asterisks in Fig 1h). A weak dispersed immunopositive signal was present in the cytoplasm of secondary spermatocytes during the second meiotic division (stage XIV, see Fig $1 \mathrm{k}, \S$ ) and some faint staining persisted in the nuclei and cytoplasm of round spermatids up to stage III.

\section{Discussion}

The detection of ERB protein in multiple testicular cell types using an anti-peptide antibody directed against the hinge domain of the receptor is consistent with detection of specific ERß mRNA in the testes of man and rat (Kuiper et al. 1997; Mosselman et al. 1996) but in conflict with the reported absence of ERB in the testis of wild type and ERKO male mice (Paech et al. 1997). It has been accepted for decades that testosterone exerts pervasive regulatory effects on the testis, and in particular on spermatogenesis (Sharpe 1994). The sites of expression of androgen receptors (AR; (Bremner et al. 1994) fit with this view, though the absence of $A R$ from germ cells has led to the conclusion that testosterone regulates spermatogenesis indirectly via stage-specific effects on Sertoli cells (Sharpe 1994). This interpretation will now need to be reconsidered in view of the present demonstration of ERB in spermatogonia and in pachytene and later spermatocytes, and other findings showing the expression of aromatase in spermatocytes, spermatids and spermatozoa (Dorrington \& Khan 1993; Janulis et al. 1996; Nitta et al. 1993). These developments raise the possibility that some of the effects of testosterone on spermatogenesis may occur directly on the germ cells after the local conversion of testosterone to oestradiol. Similarly in the fetal/neonatal testis, the demonstration of ERB in gonocytes coupled with the well-established ability of immature Sertoli cells to synthesise oestradiol (Dorrington \& Khan 1993; Weniger 1993), suggest a role for locally-produced oestradiol in the early development of primordial germ cells. This view is reinforced by the demonstration that oestradiol is able to stimulate the proliferation of gonocytes isolated from the day 3 rat testis, 

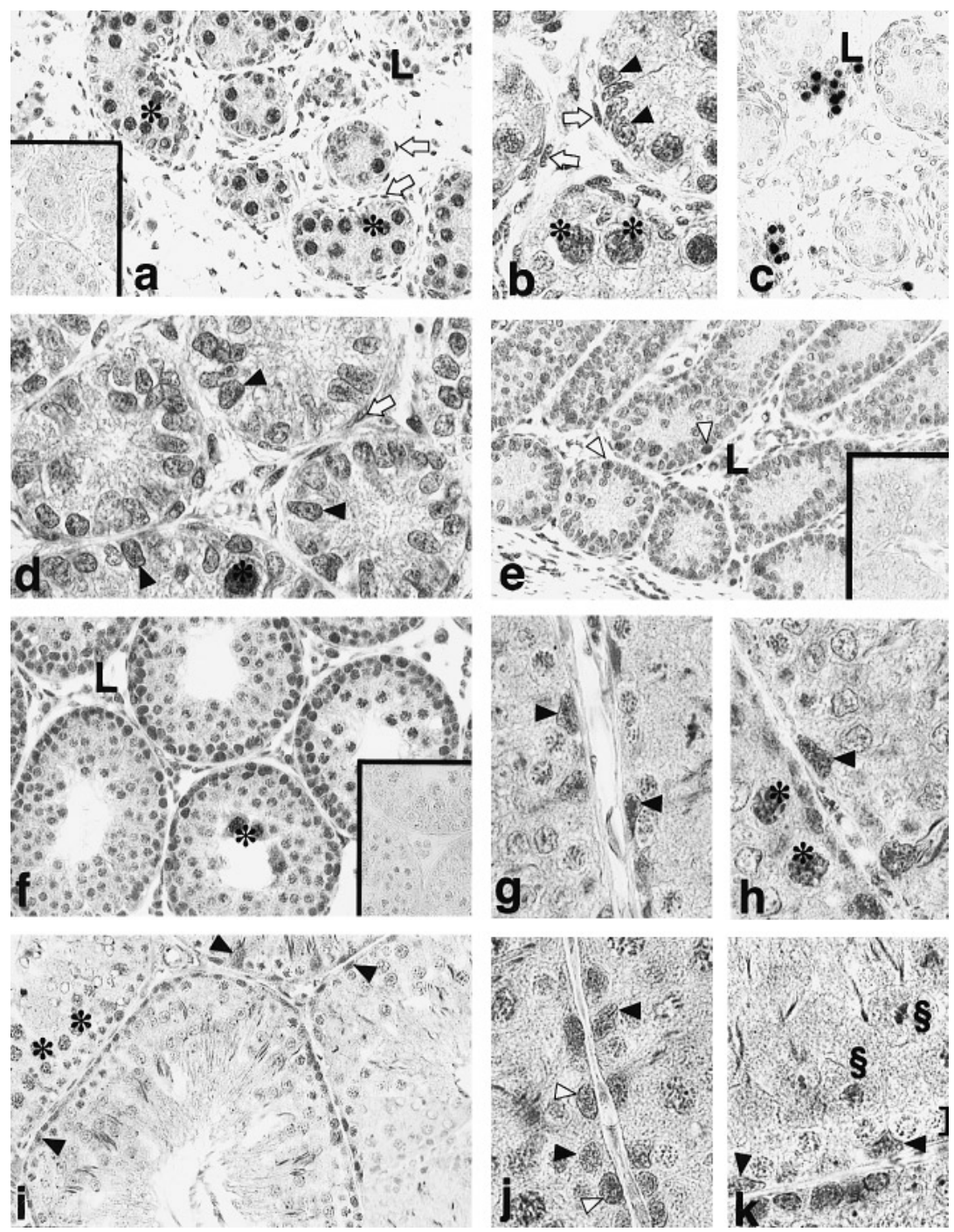

Figure 1. Immunolocalisation of ERß to multiple cell types in rat testes. All sections were lightly counterstained with haemotoxylin. a) fetal day 20.5 , inset pre-immune serum, small arrow indicates an immunopositive peritubular cell, $L=$ clump of fetal Leydig cells, $\times 40$ b) higher power view of (a). Note that within the seminiferous cords, Sertoli cell (SC) nuclei are immunopositive (arrowheads) as are those of gonocytes (asterisks); c) fetal day 20.5 immunostained with antibody specific for $E R \alpha$, note that immunopositive Leydig cells $(L)$ are only present in the interstitium, $x 40$; d) neonatal testis, day $3, x 100$, showing immunoexpression in SC nuclei (arrowheads), gonocytes (asterisk) and peritublar cells (arrow) e) immature testis, day $10, \times 40$, showing immunoexpression in SC nuclei, spermatogonia (arrows) and Leydig cells $(L)$, inset shows preimmune serum; $f$ ) pubertal day 21 , nuclei of pachytene spermatocytes contain intense immunopositive staining (asterisk), whilst in the basal portion of the tubule immunopositive staining was present in both $\mathrm{SC}$ and spermatogonia, insert shows pre-immune serum. ERß were present in nuclei of all SC (arrowheads) and some pachytene spermatocytes (asterisks) and spermatogonia (short arrows) within the seminiferous epithelium of adult rats $(\mathrm{g}, \mathrm{h}, \mathrm{i}, \mathrm{j}, \mathrm{k}$ ) in both the presence (control untreated, $g, h$ ) and absence of testosterone (i, j, k, EDS-treated, 6 days). Note that at stage XIV(k) SC nuclei are immunopositive (arrowheads), diffuse cytoplasmic staining was present in secondary spermatocytes (§) but pachytene spermatocytes (]) are not stained. 
and effect which is blocked by an oestrogen receptor antagonist (Li et al. 1997).

The present findings show that ERß was expressed in a far wider range of testicular cell types than either ER $\alpha$ or AR. Receptors for ER $\alpha$ are confined to Leydig cells and cells of the excurrent ducts (Fisher et al. 1997). AR are abundant in peritubular cells during fetal and neonatal life (Majdic et al. 1995) but not expressed in either Leydig or Sertoli cells until the testis matures postnatally (Bremner et al. 1994). In the adult rat testis, AR are expressed in Sertoli cells in a stage-dependent manner and immunoexpression is lost after androgen withdrawal induced by Leydig cell ablation with EDS (Bremner $e t$ al. 1994). In contrast, in the present study there was no evidence for stage-dependent expression of ERß in adult Sertoli cells and treatment with EDS six days previously did not affect the pattern of expression of ERß in any cell type within the seminiferous epithelium although testosterone levels are undetectable after this treatment (Sharpe et al. 1990).

The available data suggest that ER $\beta$ and $E R \alpha$ receptors have similar specificity for a wide range of ligands and bind oestradiol with similar affinity (Kuiper et al. 1997). The two ER subtypes can exist as either homodimers (ER $\alpha / E R \alpha$ or $E R B / E R ß)$ or heterodimers (ER $\alpha / E R ß)$ depending upon which types are expressed within the cell (Cowley et al. 1997; Pettersson et al. 1997). The binding affinity of ER $\alpha / E R \alpha$ and ER $\alpha$ /ER $\beta$ dimers for a consensus DNA oestrogen receptor response element (ERE) appears higher than that of ERB/ERB dimers (Cowley et al. 1997). In addition there is evidence suggesting that pattern of gene transcription induced by the ligandactivated receptor dimers may vary depending upon which form of ER dimer is formed. Paech et al. (1997) have reported that each of the homodimers showed the same transactivation profiles using a reporter gene linked to an ERE when activated with oestradiol, DES or several antiestrogens. In contrast in the same series of experiments, ER $\alpha / E R \alpha$ or ERß/ERß homodimers complexed with oestradiol were shown to signal in opposite ways at an AP-1 site. In the ERKO mouse studies of oestrogen action on the uterus suggest that other pathways of oestrogen action, independent of the presence of either ER $\alpha$ or ERß, may exist (Das et al. 1997). These findings have important implications for oestrogen regulation of cell function in the testis as we have shown that there are cell types expressing both receptors $\alpha$ and $\beta$ (Leydig cells) whereas the majority of cell types (Sertoli, peritubular myoid, gonocytes, spermatogonia and pachytene spermatocytes) express ERß alone and no cell type expresses ER $\alpha$ alone.

In conclusion, ERß is expressed in multiple cell types within the testis. Oestrogens capable of activating the receptor are present in testicular blood and can be produced locally from testosterone via the action of testicular aromatase. These findings are consistent with a role for oestrogens in modulating testicular gene expression and spermatogenesis.

\section{Acknowledgements}

We thank Julie Wilson, Sheila Macpherson, Ted Pinner and Jim Macdonald for their assistance. JSF was supported by a MRC studentship.

\section{References}

Bremner WJ, Millar MR, Sharpe RM \& Saunders PTK (1994) Immunohistochemical localization of androgen receptors in the rat testis: evidence for stage-dependent expression and regulation by androgens. Endocrinology 135 1227-1234.

Cowley SM, Hoare S, Mosselman S \& Parker SG (1997) Estrogen receptors alpha and beta form heterodimers on DNA. Journal of Biological Chemistry 272 19858-19862.

Das SK, Taylor JA, Korach KS, Paria PC, Dey SK \& Lubhan DB (1997) Estrogenic responses in estrogen receptor- $\alpha$ deficient mice reveal a distinct estrogen signally pathway. Proceedings of the National Academy of Sciences USA 94 12786-12791.

Dorrington JH \& Khan SA (1993) Steroid production, metabolism, and release by Sertoli cells. In The Sertoli Cell pp 538-549. Eds L. Russell \& M. Griswold. Clearwater: Cache River Press.

Eddy EM, Washburn TF, Bunch DO, Goulding EH, Gladen BC, Lubahn DB \& Korach KS (1996) Targeted disruption of the estrogen receptor gene in male mice causes alteration of spermatogenesis and infertility. Endocrinolgy 137 4796-4805.

Fisher J, Millar MR, Majdic G, Saunders PTK, Fraser HM \& Sharpe RM (1997) Immunolocalisation of oestrogen receptor-alpha $(E R \alpha)$ within the testis and excurrent ducts of the rat and marmoset monkey from perinatal life to adulthood. Journal of Endocrinology 153 485-495.

Janulis L, Bahr JM, Hess RA \& Bunick D (1996) P450 aromatase messenger ribonucleic acid expression in male rat germ cells: detection by reverse transcription-polymerase chain reaction. Journal of Andrology 17 651-658.

Kuiper GGJM, Carlsson B, Grandien K, Enmark E, Haggblad J, Nilsson S \& Gustafsson J-A (1997) Comparison of the ligand binding specificity and transcipt tissue distribution of estrogen receptors alpha and beta. Endocrinology 138 863-870.

Kuiper GGJM, Enmark E, Pelto-Hukko M, Nilsson S \& Gustafsson J-A (1996) Cloning of a novel estrogen receptor expressed in rat prostate. Proceedings of the National Academy, USA 93 59255930.

Li H, Papadopoulos V, Vidic B, Dym M \& Cluty M (1997) Regulation of rat testis gonocyte proliferation by platelet derived growth factor and estradiol: identification of signalling mechanisms involved. Endocrinology 138 1289-1298.

Majdic G, Millar MR \& Saunders PTK (1995) Immunolocalisation of androgen receptor to interstitial cells in fetal rat testes and to mesenchymal and epithelial cells of associated ducts. Journal of Endocrinology 147 285-293.

Millar MR, Sharpe RM, Maguire SM \& Saunders PTK (1993) Cellular localisation of messenger RNAs in rat testis: application of digoxigenin labelled probes to embedded tissue. Cell and Tissue Research 273 269-277.

Mosselman S, Polman J \& Dijkema R (1996) ERbeta: identification and characterization of a novel human estrogen receptor. FEBS letters 392 49-53.

Nitta H, Bunick D, Hess RA, Janulis L, Newton SC, Millette CF, Osawa Y, Shitzuta Y, Toda K \& Bahr JM (1993) Germ cells of the 
mouse testis express P450 aromatase. Endocrinology 1321396 1401.

Paech K, Webb P, Kuiper GGJM, Nilsson S, Gustafsson J-A, Kushner PJ \& Scanlan TS (1997) Differential ligand activation of estrogen receptors ER $\alpha$ and ER $\beta$ at AP1 sites. Science 277 1508-1510.

Pettersson K, Grandien K, Kuiper GGJM \& Gustafsson J-A (1997) Mouse estrogen receptor $\beta$ forms estrogen receptor response element-binding heterodimers with estrogen receptor $\alpha$. Molecular Endocrinology 11 1486-1496.

Saunders PTK, Maguire SM, Gaughan J \& Millar MR (1997) Expression of oestrogen receptor beta $(E R \beta)$ in multiple rat tissues visualised by immunohistochemistry. Journal of Endocrinology 154 R13-R16.

Sharpe RM (1994) Regulation of Spermatogenesis. In The Physiology of Reproduction, 2nd Edn pp 1363-1434. Eds E. Knobil \& J. D. Neill. New York: Raven Press.

Sharpe RM, Maddocks S \& Kerr JB (1990) Cell-cell interactions in the control of spermatogenesis as studied using Leydig cell destruction and testosterone replacement. American Journal of Anatomy 188 3-20.

Sharpe RM \& Skakkebaek NE (1993) Are oestrogens involved in falling sperm counts and disorders of the reproductive tract? Lancet 341 125-126.
Shi S-R, Chaiwun B, Young L, Cote RJ \& Taylor CR (1993) Antigen retrieval technique utilizing citrate buffer or urea solution for immunohistochemical demonstration of androgen receptor in formalin-fixed paraffin sections. Journal of Histochemistry and Cytochemistry 41 1599-1604.

Smith EP, Boyd J, Frank GR, Takahashi H, Cohen RM, Specker B, Williams TC, Lubahn DB \& Korach KS (1994) Estrogen resistance caused by a mutation in the estrogen-receptor gene in a man. New England Journal of Medicine 331 1056-1061.

Stillman RJ (1982) In utero exposure to diethylstilbestrol: adverse effects on the reproductive tract and reproductive performance in male and female offspring. American Journal of Obstetrics and Gynecology 142 905-921.

Toppari J, Larsen JC, Christiansen P, Giwercman A, Grandjean P, Guillette LJ, Jegou B, Jensen TK, Jouannet P, Keiding N, Leffers H, McLachlan JA, Meyer O, Muller J, Rajpert-De Meyts E, Scheike T, Sharpe RM, Sumpter J \& Skakkebaek NE (1996) Male reproductive health and environmental xenoestrogens. Environmental Health Perspectives 104 741-803.

Weniger J-P (1993) Estrogen production by fetal rat gonads. Journal of Steroid Biochemistry and Molecular Biology 44 459-462. 